Nova Southeastern University

Florida

NOVA SOUTHEASTERN

UNIVERSITY

NSUWorks

Marine \& Environmental Sciences Faculty Articles Department of Marine and Environmental Sciences

7-5-2012

\title{
Circle Hooks in Commercial, Recreational, and Artisanal Fisheries: Research Status and Needs for Improved Conservation and Management
}

Joseph E. Serafy

National Oceanic and Atmospheric Administration, <<span class="elink">joe.serafy@noaa.gov

Steven J. Cooke

Carleton University - Ottawa, Canada

Guillermo A. Diaz

National Oceanic and Atmospheric Administration

John E. Graves

College of William and Mary

Martin Hall

Inter-American Tropical Tuna Commission

See next page for additional authors

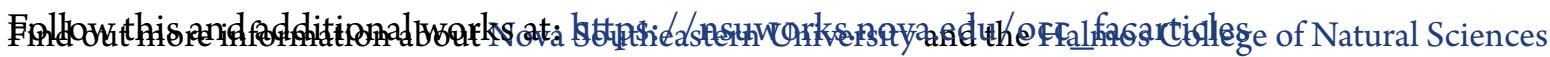

Partofragrepharine Biology Commons, and the Oceanography and Atmospheric Sciences and Meteorology Commons

\section{NSUWorks Citation}

Joseph E. Serafy, Steven J. Cooke, Guillermo A. Diaz, John E. Graves, Martin Hall, Mahmood S. Shivji, and Yonat Swimmer. 2012. Circle Hooks in Commercial, Recreational, and Artisanal Fisheries: Research Status and Needs for Improved Conservation and Management.Bulletin of Marine Science , (3) : 371 -391.https://nsuworks.nova.edu/occ_facarticles/360.

This Article is brought to you for free and open access by the Department of Marine and Environmental Sciences at NSUWorks. It has been accepted for inclusion in Marine \& Environmental Sciences Faculty Articles by an authorized administrator of NSUWorks. For more information, please contact nsuworks@nova.edu. 
Authors

Mahmood S. Shivji

Nova Southeastern University, mahmood@nova.edu

Yonat Swimmer

National Oceanic and Atmospheric Administration 


\title{
CIRCLE HOOKS IN COMMERCIAL, RECREATIONAL, AND ARTISANAL FISHERIES: RESEARCH STATUS AND NEEDS FOR IMPROVED CONSERVATION AND MANAGEMENT
}

\author{
Joseph E Serafy, Steven J Cooke, Guillermo A Diaz, \\ John E Graves, Martin Hall, Mahmood Shivji, \\ and Yonat Swimmer
}

\begin{abstract}
The intent of convening the International Symposium on Circle Hooks in Research, Management, and Conservation was to yield a contemporary, sciencebased assessment of the management and conservation utility of circle hooks in commercial, recreational, and artisanal fisheries around the globe. The symposium objective was to provide a forum for individuals, organizations, and agencies to share relevant research results and perspectives. Based on the presentations, an examination of the literature, and the collective experience and knowledge of the authors, we provide a brief overview of the current status of circle hook research along with a list of research needs, with a particular focus on science that has the potential to inform managers and stakeholders. Progress was made on the definition of a "true circle hook." There was strong recognition that circle hooks represent just one of the tools available to managers for reducing bycatch and release mortality. Also defined was the need for an integrative approach that considers strategies that complement the use of circle hooks. Some of the research needs identified include a greater emphasis on human dimension studies to identify those factors that may impede adoption of circle hook technology by stakeholders and comparative studies of circle hook performance relative to mouth morphology, dentition, and feeding behavior. While the literature on effective use of circle hooks is growing, there remains a number of unanswered questions that will require study before circle hooks are more widely adopted for conservation and management of aquatic living resources.
\end{abstract}

\section{BACKGROUND}

In most hook-and-line fisheries around the globe, the standard practice is, and has been, to use a "J-shaped" hook, or Japanese-style "tuna hook." However, based on the results of a few key studies conducted over the last decade, a growing number of commercial, recreational, and artisanal fisheries are now employing "circle hooks." Circle hooks tend to cause less injury to captured animals because they typically lodge in the lower jaw or jaw hinge as opposed to hooking in more damaging areas, such as the esophagus, respiratory organs, or roof of the mouth (see reviews by Cooke and Suski 2004, Read 2007, Serafy et al. 2009, Godin et al. 2012, Graves et al. 2012). Physically, a circle hook differs from a J-hook in numerous ways, although a comprehensive definition has been lacking. As its name suggests, a circle hook has a rounded shape and its point is oriented perpendicular to the shank; in comparison, a J-hook is less rounded and its point is oriented parallel to the shank. These 
shape and point-to-shank orientation differences, combined with numerous other aspects of hook size, configuration, and mode of deployment, can change catch rates of both target and bycatch species, while also affecting the condition (i.e., live/dead, damaged/injured) of hooked animals. In many, but not all cases, circle hook use has been associated with improved condition of captured individuals, both of the species targeted and those captured unintentionally (Cooke and Suski 2004, Watson et al. 2005, Kerstetter and Graves 2006, Diaz 2008, Epperley et al. 2012, Serafy et al. 2012b). Conceptually, improved condition is desirable for bycatch or non-target animals that are released, including species that have little or no nutritional or economic value, undersized individuals of target species, individuals from overfished, threatened, or endangered populations, and fish that are solely the target of recreational catch-and-release fisheries (Hall et al. 2000, Kennelly and Broadhurst 2002). Likewise, improved condition at capture may also be desirable for animals targeted and retained by the fishery, provided it leads to a higher quality product (and price) in the market. Of course, one fisher's bycatch is another's target and vice versa, and there is no simple answer to the question: When, where, and under what circumstances are circle hooks a good or a bad idea, or somewhere in between?

Apparent from the recent surge of research into the efficacy and impacts of circle hooks is that: (1) study outcomes have varied; and (2) inconsistencies remain surrounding hook definition, measurement, performance evaluation, and adoption. Circle hook study outcomes vary depending on the: hook types (shapes) and dimensions compared; target or bycatch species and body sizes examined; performance measures (e.g., catch, mortality, and injury rates) investigated; study designs adopted; statistical analyses performed; and numerous other factors associated with bait, fishing technique, environment, and region of study. Mixed findings should not be surprising given the wide array of target and bycatch species, fishery sectors and economies, and fishing cultures and techniques that have been examined. Circle hooks can affect catch, initial mortality and injury rates, and lead to hookings in anatomical locations that facilitate or impede subsequent live release. In some cases, several of the above effects may be present, in others only one or two, which complicates evaluation of the pros and cons both within and across studies

The heterogeneity of study approaches, results, and objectives has hindered meaningful assessment of potential or realized impacts of circle hook use at the population, ecosystem, and socioeconomic levels. Because interpreting and synthesizing heterogeneous studies and their results is difficult, and resistance to changing traditional fishing practices is the norm, circle hook performance has not been adequately tested, let alone their use adopted, in fisheries where circle hooks might extend conservation and/or economic benefits. For these benefits to be fully realized, greater consensus among the international scientific, management (including law enforcement), and conservation communities is required as to what defines a circle hook and under what circumstances this relatively inexpensive technology should, and should not, be applied. The general lack of uniformity among empirical research efforts, absence of hook size standards, and disagreements as to those specifications or characteristics that define a circle hook have hindered definitive assessment of the pros and cons of circle hook use for a comprehensive list of target and bycatch species. To assess the state of circle hook science and identify and key needs in circle hook research, management, and conservation, a dedicated circle hook symposium was 
seen as an essential step for developing much-needed uniformity in the definition of circle hooks and in the application of research approaches, and for fostering greater collaboration among the international scientific and conservation communities.

\section{SyMPOSIUM OVERVIEW}

The International Symposium on Circle Hooks was held in Coral Gables, Florida, USA, from 4 to 6 May, 2011, under the auspices of the US National Marine Fisheries Service and with the support of several non-governmental entities. The goal of the symposium was to produce an updated, science-based assessment of the management and conservation utility of circle hooks in commercial, recreational, and artisanal fisheries around the globe. The symposium was not a venue for advocating widespread use of circle hooks; rather, the objective was to provide a forum for individuals, organizations, and agencies to share relevant research results and perspectives and to subject their findings to peer-review by an internationally-recognized scientific journal. The symposium sessions included: (1) circle hooks defined; (2) circle hooks and commercial fisheries; (3) circle hooks and recreational fisheries; (4) circle hooks and sharks; (5) circle hooks and sea turtle bycatch; (6) circle hooks and human dimensions; and (7) circle hooks in assessment and management.

The symposium attracted about 180 attendees, which included researchers, resource managers, and outreach specialists from over 20 nations around the world ${ }^{1}$. There were 82 oral and poster presentations leading to submission of 32 manuscripts to the Bulletin of Marine Science; 25 of which were accepted for publication and appear in this special issue (Serafy et al. 2012a). A breakdown of the number of all presentations by topic is shown in Figure 1. Below is a summary of the findings presented with notes on new developments and emerging themes including an overview of research needs that we hope will direct future research activities and fully define the utility of circle hooks as a tool for conservation and management of aquatic resources.

\section{Circle Hooks Defined}

The lack of a consistent definition of what constitutes a circle hook has undoubtedly led to differing impressions of hook effectiveness. The terminology describing the basic "anatomy" of a fish hook, including a circle hook, is not problematic-there is general consensus as to what constitutes the eye, shank, bend, barb, point, and gap of a given hook and whether it is "inline" or "offset" (Fig. 2). However, differences arise among manufacturers, fishers, and researchers as to which linear and angular measurements determine hook style (shape) and size. Lack of a circle hook definition complicates law enforcement, in some cases forcing management to name specific manufacturers and models, which may not be a desirable situation for entities expected to be impartial with regard to hook providers. Important progress was made

1 List of nations (24) with one or more contributors (manuscript, abstract, and/or oral presentation) to the "International Symposium on Circle Hooks in Research, Management, and Conservation" held May 4-6, 2011, in Coral Gables, Florida, USA: Australia, Brazil, Canada, China, Colombia, Costa Rica, Ecuador, Guatemala, Indonesia, Italy, Japan, Mexico, Morocco, Nicaragua, Norway, Panama, Peru, Portugal, Spain, Taiwan, Thailand, United Kingdom, United States, and Uruguay. 
during the symposium with respect to the definition of a circle hook. Geir Sivertzen, a former engineer of a major hook manufacturer, proposed that a "true circle hook" has all three of the following characteristics:

1. Angle of the point to the shank must be a minimum of $90^{\circ}$,

2. Angle of the front length of the hook must bend a minimum of $20^{\circ}$ toward the shank, and

3. The front length of the hook should be $70 \%-80 \%$ of the hook's total length.

This proposed definition was met with great interest and no opposition; therefore, it can serve as a framework for future experimental fishing trials where gradients in each of the three true circle hook characteristics are explicitly tested.

Hook offset, the angular deviation of the point from the center line of the shank, has been shown to potentially affect catch, injury, and mortality rates of captured organisms (Swimmer et al. 2010, Epperly et al. 2012, Rice et al. 2012). There are difficulties measuring angular degree of offset and it was suggested that another linear measurement, offset width, may be more relevant and certainly easier to quantify using calipers (Yokota et al. 2012). Offset width is the linear distance from the point to the plane of the shank's center line. A large and small hook with identical offset angles will have different offset widths. Several studies indicate that deep-hooking tends to decrease with increasing (overall) hook size (e.g., Curran and Beverly 2012, Leaman et al 2012, Patterson et al. 2012). However, these benefits may be reduced or eliminated as hook offset width (and angle) increases.

Lack of uniformity in how hooks are sized remains a critical unresolved problem. Add to this the problem of cultural and regional differences in terminology related to hook design, which is particularly problematic for multi-national fisheries management bodies [see Beverly et al. (2003) for examples of differences in terminology and measures used]. In some cases, managers have identified specific manufacturers, models, and sizes that are acceptable (i.e., legal) for use as enforcement efforts would be ineffective without a clear definition that would withstand scrutiny by the judiciary. We are unaware of any other hook type or design for which that level of regulatory detail or guidance is provided emphasizing the challenges of not having a globally consistent definition of circle hooks. A step toward a consistent definition may lie in the production of region-specific hook catalogs (e.g., Mituhasi and Hall 2011) and morphometric analysis using the Sivertzen's "true circle hook" criteria described above.

\section{Circle Hooks and Commercial Fisheries}

Resistance to circle hook use is virtually ensured unless equivalent or higher target catch or significant improvements in flesh quality result from their use. Most of the presentations in the session focusing on circle hooks and commercial fisheries described experimental fishing studies conducted with pelagic longlines targeting swordfish and tunas and, in some cases, billfish and sharks (e.g., Cambiè et al. 2012, Coelho et al. 2012, Curran and Beverly 2012, Foster et al. 2012, Gadea et al. 2012, Domingo et al. 2012). Comparisons of catch, bycatch, and survival rates (proportion of animals alive at gear retrieval-haul back), as well as animal size-frequency distributions and anatomical hooking locations were made for: (a) one or two types 


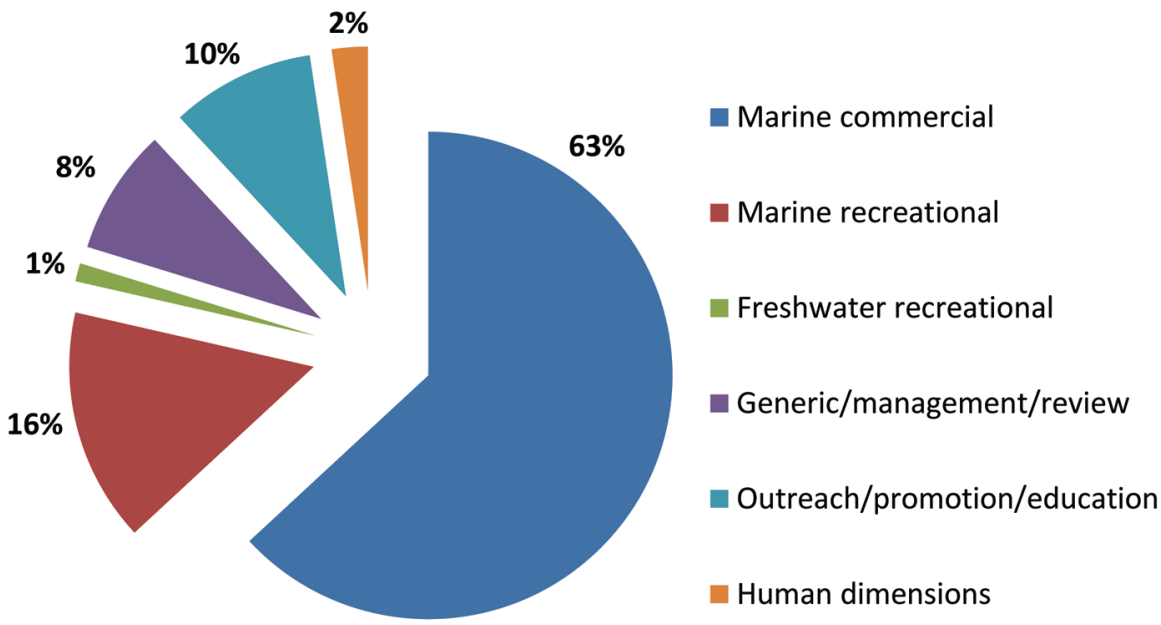

Figure 1. Breakdown by major topic area of all presentations (oral and poster) given at the International Symposium on Circle Hooks, May 4-6, 2011, Coral Gables, Florida.

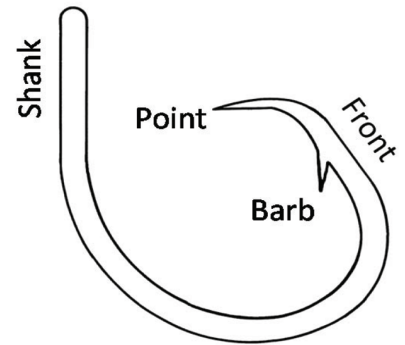

Bend

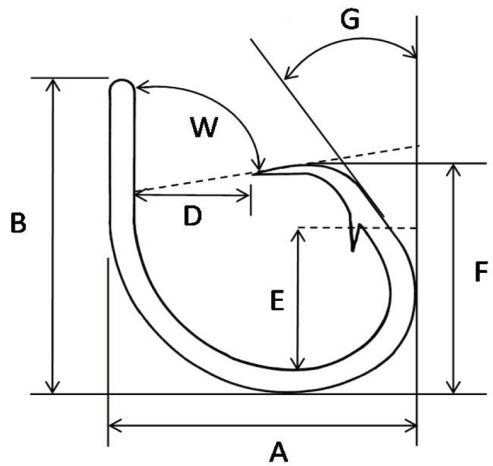

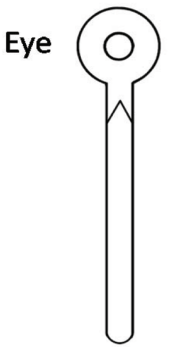
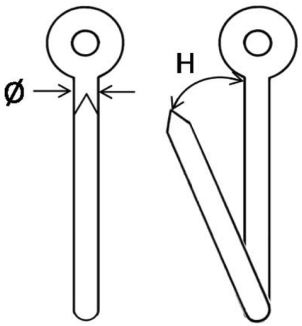

Figure 2. Anatomy of a circle hook. Basic components (upper panel) and measurements (lower panel): (A) width; (B) length; (D) gap; (E) throat; (F) front length; (W) point angle; (G) front angle; $(\mathrm{H})$ offset angle; $(\varnothing)$ wire diameter. Lettering conforms to hook manufacturer conventions. 
of circle hook vs a J-hook; or (b) two or more types of circle hook of different size, strength, or offset.

As is the case with any alternative fishing technology, one of the primary research questions is whether circle hook use impacts the catches of the target species. Unless the catch rates of target species are demonstrated to be unaffected or increased as a result of circle hook use, their voluntarily adoption is unlikely. However, even if target catch rates decrease, if (seafood) quality improves, higher prices may make up for catch losses. Most of the presented studies made direct circle hook vs noncircle hook catch rate comparisons. As one might expect, results varied due to wide diversity in fishing techniques, species caught, and environments fished. Inter-study differences in catch rates for the same species in the same region may be driven by differences in circle hook size and/or bait, thus it is important to consider such details in cross-study comparisons. Furthermore, some of the variation among study results undoubtedly occurred due to differences in the way data were analyzed and reported. At the most basic level was the researchers' choice of catch units, specifically, whether catch per unit effort (CPUE) was expressed in terms of numbers of fish or weight (biomass). In recreational fishing studies and in most bycatch evaluations, this tends not to be a problem as catch rates are almost universally reported in numbers of fish caught per unit of effort. But, in many commercial fisheries, expression of target catch in terms of weight is more common because fishers are typically paid for the total weight of their landings, not for the numbers of fish caught, and most fisheries statistics of commercial fisheries correspond to data collected of landings in weight rather than in number of individuals. A practice that would simplify interstudy comparisons, and facilitate meta-analyses, is the reporting of catch rates of target species and associated statistics in both number and weight units-a rarity in the circle hook literature. Weight determination can be difficult at sea, however, length data are typically recorded, which allows for weight estimation via weightlength relationships.

Another source of variation among circle hook study results relates to the statistical approaches adopted by investigators. Analytical methods included simple ANOVA-based comparisons, chi-square tests, permutation tests, paired $t$-tests, and regression modeling approaches that assumed delta-lognormal, tweedie, or other distributions. Discussion of the statistical methods of analyses can be found in IATTC (2008). This heterogeneity among analytical methods, combined with different catch units, sample sizes, and criteria for declaring statistical significance represented an obstacle in the search for general patterns of circle hook impacts across species, fisheries, and/or environments. This suggests that careful meta-analyses of circle hook results will continue to have an important role.

Several studies of longline fisheries targeting swordfish and tuna species reported swordfish catch reductions (only with squid bait, and not with fish bait) on circle hooks relative to J-hooks, whereas tuna catches were found to increase (Watson et al. 2005, Coelho et al. 2012, Domingo et al. 2012, Giffoni et al. 2012). Two studies (Epperley et al. 2012, Richards et al. 2012) comparing $10^{\circ}$ offset and non-offset circle hooks reported no differences in target or bycatch rates of all species considered. However, with longline gear, higher mortality rates are often observed when fishing with $10^{\circ}$ offset vs non offset hooks (Epperly et al. 2012, Rice et al. 2012). A generally consistent result among studies (regardless of the species, fishery, or region examined) was the tendency for a higher proportion of mouth hooking with circle hooks 
as opposed to J-hooks, which were more prone to deep hooking. This was evident in studies examining a wide diversity of teleosts, sharks, and sea turtles. Therefore, the new data presented at the symposium continue to support the notion that the severity of hooking injury is reduced by circle hooks; thus, benefitting animals destined for release, as the result of the nature of the fishery or due to management regulations. The release of bycatch as a management tool to reduce fishing mortality on these species would be ineffective if a large proportion of animals are dead upon gear retrieval or experience low post-release survival as a result of hook injuries. However, several studies demonstrated the use of circle hooks in longline fisheries increased the proportion of fish that are alive at gear haulback and that some species have a very high post-release survival (Epperly et al. 2012, Serafy et al 2012b).

Recent experimental work describes "weak" circle hooks as a potential means of reducing large organism bycatch, such as spawning bluefin tuna, Thunnus thynnus (Linnaeus, 1758), in the Gulf of Mexico (GOM) and the false killer whale, Pseudorca crassidens (Owen, 1846), a protected marine mammal, in the Pacific Ocean (Bigelow et al. 2012, Foster and Bergmann 2012). Weak circle hooks are constructed of thinner gauge stock wire than standard circle hooks of the same size, and they are designed to straighten at a lower strain (pull) level than standard hooks, thereby allowing large hooked animals to escape while retaining the target catch. For example, fishing trials were conducted in the GOM aboard pelagic longline vessels comparing target catch and bycatch rates on $3.65-\mathrm{mm}$ gauge weak hooks vs $4.00-\mathrm{mm}$ gauge standard circle hooks (16/0 size hooks). The results of these trials showed significantly lower bluefin tuna catch rates with weak hooks compared to the control hooks and non-significant reduction in the catch rates of yellowfin tuna, the target species. This finding led to the rapid enactment (i.e., May 2011) of a US federal regulation requiring the mandatory use of these weak hooks for all longline vessels fishing in the GOM. Experimental results from a Hawaii-based pelagic longline fishery suggested that the use of weak hooks may benefit large marine mammals and other bycatch species, with little impact on tuna catches. However, some results were unexpected, with significant catch increases in some species and a pattern of smaller tuna straightening weak hooks more so than larger ones (Bigelow et al. 2012). Unaddressed in weak hook studies conducted to date is that both the identity and fate of organisms that escape capture by straightening hooks is essentially unknown. While weak hooks may lead to reduced catch rates for certain organisms, their conservation value cannot be fully assessed until the extent of injury and post-escape survival of weak hook straightening organisms are determined. The same is true when considering reduced shark catches when fishing with terminal gear of monofilament, which hooked sharks are able to sever, but their subsequent fate is unknown (see below).

There has been recent interest in the use of circle hooks with either magnetic or galvanic properties in hook-and-line fisheries where sharks and rays are part of the bycatch. In laboratory studies, both have been shown to evoke avoidance behavior in some sharks and rays, presumably by interfering with their electricity-sensing ampullary organ, an organ that is absent in teleosts. So far, results from fishing-based field studies have been mixed (Kaimmer and Stoner 2008, Tallack and Mandelman 2009, Robbins et al. 2011). Stroud et al. (2012) combined magnetic and galvanic compounds into a polymer fixative coating to apply to hooks, including a circle hook. Further testing of this approach is underway and if successful and feasible, may hold promise for reducing shark catches in those fisheries that seek to avoid them. 


\section{Circle Hooks and Recreational Fisheries}

Circle hooks have become popular in recreational fisheries and there has been a reasonable amount of research evaluating circle hook performance (e.g., mortality, injury, hooking efficiency) relative to other hook designs for a number of marine and freshwater species (reviewed in Cooke and Suski 2004). The symposium was dominated by marine circle hook studies, most focusing on multiple rather than single species given that most marine recreational fisheries target multiple species. Examples come from the Mediterranean Sea (Alós and Cabanellas-Reboredo 2012), the GOM (e.g., Patterson et al. 2012, Sauls and Ayala 2012), and Australia (Grixti et al. 2012). One important message was that there was greater opportunity to include multivariate techniques in data analysis (this message could be extended to the commercial sector as noted above). For example, a study from the Balearic Islands in the Mediterranean Sea (Alós and Cabanellas-Reboredo 2012) used principal component analysis and redundancy analysis to demonstrate that catch rates remained generally constant when circle hooks and conventional J-hooks were compared.

Another innovative approach was the incorporation of studies of functional morphology and feeding mechanics into comparative hook investigations. A study on red grouper, Epinephalus morio Poey, 1860 and red snapper, Lutjanus campechanus Poey, 1860, in the GOM (Burns and Froeschke 2012) demonstrated that variation in ecomorphology underlies differences in J-hook and circle hook mortality between the two species and, therefore, ecomorphological studies can be useful for better understanding and predicting circle hook performance in a wide range of species. Burns and Froeschke (2012) and Parkyn and Murie (2012) also inferred relative survival rates of fish captured with J- vs circle hook from tag return data. This general approach warrants broader application in ongoing and future fish tagging programs.

In studies on tarpon in Florida (Guindon 2012) and dolphinfish, yellowfin tuna, and wahoo off the coast of North Carolina (Rudershausen et al. 2012), hooking rates and/or landing rates declined when using circle hooks rather than J-hooks. There were also a range of circle hook studies that systematically varied hook sizes and the presence of barbs. Circle hook size has been identified as an important factor that can be regulated (or encouraged) as part of an overall management strategy if there is interest in making fisheries more selective (Graves et al. 2012, Patterson et al. 2012).

Meyer et al. (2012) focused exclusively on freshwater recreational fisheries and explored an important question that is fundamental to the use of circle hooks in the recreational sector-are the benefits of circle hooks (i.e., shallow hooking, reduced morality) exclusively for passive fishing approaches or do they extend to active fishing (Cooke and Suski 2004)? These researchers from the Idaho Department of Fish and Game obtained unexpected results from experiments conducted with wild trout in several freshwater streams. In a variety of independent studies, deep-hooking was higher for passively fished bait when compared to actively fished baits, which was opposite to the prevailing thought (Meyer et al. 2012). Grixti et al. (2012) also emphasized the importance of passive vs active angling techniques on mortality of marine fishes in Australian waters. Clearly, additional research on this important topic is needed.

Although not specific to circle hooks, one study explored a modified J-hook that allowed fish to escape prior to landing (self-releasing; Gude et al. 2012). The premise 
may seem odd, but the hook was tested to see whether it would enable recreational fishing to be a sustainable practice in protected ecosystems which support a large biomass of higher predators and where release mortality due to predation is consequently quite high. Exploration of alternative hook designs is still necessary as circle hooks are by no means a panacea.

\section{Circle Hooks and Sharks}

Although typically small or artisanal in nature, targeted shark fisheries exist in many parts of the world; however, most shark capture is believed to occur as bycatch in pelagic longline commercial fisheries (Lewison et al. 2004, Watson and Kerstetter 2006). With widespread concerns that most large shark species cannot sustain ongoing levels of exploitation, circle hook use is being investigated, and in some cases recommended, as a tool for reducing shark bycatch and/or increasing the survival of sharks on the line.

From a global perspective, a reduction in shark bycatch rates, as opposed to a reduction in hooking mortality, is preferred because even sharks that are still alive when the lines are retrieved can still be potentially finned in unregulated fisheries. However, conservation benefits would also accrue if the use of circle hooks results in a significant reduction in at-vessel mortality compared to J-hook use in regulated fisheries where no-retention policies for certain shark species, or non-finning regulations and adequate enforcement exist, as live sharks would be released.

The utility of circle hooks to reduce shark bycatch and/or at-vessel mortality has received much less attention to date compared to other bycatch species such as marine mammals and sea turtles. Godin et al. (2012) conducted a timely review of studies that directly addressed this topic. Their meta-analysis of the data from 23 studies provided a mixed picture. Overall, analysis of combined data from 18 studies (all species combined) demonstrated no significant difference in shark catchability between circle hooks and J-hooks in pelagic longline fisheries. However, there was a high level of heterogeneity in the results, with some studies indicating a slight increase in shark bycatch with circle hook use, an undesirable conservation outcome. The results of a study by Afonso et al. (2012), which was not included in the Godin et al. (2012) meta-analysis, also found no significant difference in shark bycatch between the two hook types. Results from the two shark-directed demersal fisheries reviewed were equivocal, with one study demonstrating an increase and the other a decrease in shark catch on circle hooks.

The Godin et al. (2012) meta-analysis of combined data from eight studies examining mortality rates in pelagic longline fisheries supported the hypothesis of reduced at-vessel mortality of sharks captured on circle hooks (all species combined and blue sharks individually). This result was coincident with the finding that, in most studies reviewed (there were two exceptions), sharks captured on circle hooks were more frequently hooked in the mouth or jaw rather than internally. It is assumed that this external hooking is the major factor reducing at-vessel mortality rates. In contrast, the study by Afonso et al. (2012) did not detect a significant difference in shark atvessel mortality between the two hook types.

There were also studies presented at the symposium (not included in this issue), that highlighted to importance of other gear characteristics, such as leader and line material, which can greatly shark capture rates. Ingram et al. (2012) and Afonso et al. 
(2012) both reported higher shark catch on wire compared to monofilament leaders. Wire is used in fisheries targeting sharks to prevent sharks biting off the line. Ingram et al. (2012) suggested that the mandatory use of monofilament in pelagic longline fisheries may serve as a management option to reduce the bycatch of pelagic sharks. However, as is the case with the weak hooks, reduced shark catch rates resulting from the use of monofilament leaders may not necessarily equate to reduced shark mortality (Afonso et al. 2012) as the extent of the injury due to hooking cannot be assessed.

Overall, the symposium results presented a mixed view of the utility of circle hooks as a shark conservation tool; however, the combination of circle hooks and shorter longline sets holds promise given the lack of viable alternatives to reduce shark mortality with longline fishing. Circle hooks may provide some benefits in reducing overall at-vessel mortality in commercial fisheries. Assuming this reduced mortality also leads to increased post-release survival, the use of circle hooks could very well prove beneficial for shark conservation in well regulated fisheries. However, it remains unclear whether circle hook use may also increase the bycatch of sharks overall, an outcome that would have the undesired effect of increasing shark mortality in the mostly unregulated (as far as shark bycatch is concerned) global pelagic longline fisheries (Kaplan et al. 2007). The symposium results do, however, point to clear research needs with regard to shark conservation and management. Whether circle hooks result in increased shark bycatch needs to be investigated more thoroughly to derive a picture of utility of circle hooks as an effective shark conservation tool in global pelagic longline fisheries. The review by Godin et al. (2012) highlights the large amount of heterogeneity in the study results, which prevents the emergence of an unambiguous picture to guide policy on broad implementation of circle hooks as a shark conservation tool. This heterogeneity undoubtedly results from the lack of standardization in the types of fishing gear (including bait types, size of hooks, hook offsets, leader types, etc.) and assessment methodology used in different studies. Symposium outcomes underscore a great need for carefully designed experiments to allow comparison of results across different studies. A scientific consensus on the utility of circle hooks as an important shark management and conservation tool is dependent on such studies.

\section{Circle Hooks and Sea Turtle Bycatch}

Circle hooks have been shown to significantly reduce the frequency of hooking events as compared to J-hooks or tuna hooks, and they are more likely to result in superficial hooking, such as in the jaw or flipper, as compared to more frequent deep ingestions of hooks observed on J-hooks or tuna hooks. Hence, when properly handled, a sea turtle with a superficial hooking is believed to have a higher probability of survival after being released than a deep-hooked animal.

The use of relatively large circle hooks (e.g., 18/0) in combination with finfish bait can significantly reduce the frequency of hooking of sea turtles when compared to traditional J-hooks or tuna hooks (and squid bait; e.g., Watson et al. 2005, Read 2007, Gilman et al. 2006, Sales et al. 2010). As such, the US and some regional fisheries management organizations (RFMOs) consider circle hooks to be an effective tool to reduce sea turtle bycatch in pelagic longline fisheries. At the symposium, additional studies were presented that compared capture rates of sea turtles in longline fisheries. The majority of studies that compared sea turtle capture rates by hook type 
found that use of large circle hooks significantly reduced sea turtle capture rates compared to J-hooks (Caicedo Pantoja et al. 2012, Gadea et al. 2012, Martinez et al 2012, Pacheco and Pons 2012, Santos et al. 2012, Stokes et al. 2012, Villagran et al. 2012), while smaller circle hooks had limited conservation benefits (Cambiè et al. 2012); however, other factors such as bait also must be considered either in future studies or during implementation of regulations.

The use of circle hooks can reduce the proportion of sea turtles that swallow the hooks as compared to the traditional J-hooks with squid bait (Watson et al 2005, Read 2007, Sales et al. 2010). It has been speculated that more superficial hooking events lead to higher post-release survival than when hooks are swallowed. As such, use of circle hooks could result in lower mortality of sea turtles incidentally caught and released from longline gear.

Recent research has addressed the issue of increasing turtles' post-release survival through a number of means. For example, Arauz et al. (2012) described sea turtle release devices that eliminate the need to bring turtles onto the boat for dehooking purposes. Not only did "release hooks" facilitate the dehooking process as intended, but the hooks also reduced turtle catch rates. Hataway and Stokes (2012) conducted studies with captive turtles and found that deep ingestion rates decreased as hook and turtle size increased. The addition of a wire appendage to the hook, however, did not influence rates of deep ingestion. Use of circle hooks vs J-hooks was also found to result in a significantly lower proportion of turtles that deeply ingested the hooks compared to superficial hookings in a number of studies (Pacheco and Pons 2012, Villagran et al. 2012).

More recent research suggests that regardless of the hook type, a critical factor affecting sea turtle post-release survival is the length of the line that remains attached to the hook after the animal is released (Parga 2012). Line left trailing will eventually be swallowed by the sea turtle, and this may be lethal. Other best handling practices that can increase post-release survival include using a dip net to board turtles, cutting the line as close to the hook as possible, removing visible hooks that are externally lodged (e.g., in the mouth), while ensuring minimal harm to the animal. Attempts to remove hooks by non-trained or inexperienced fishers can result in life threatening injuries that include extensive infections in the areas where the hooks were lodged. Research has shown that many deep hookings that occur without puncturing non-vital organs can eventually result in the hook being dissolved or expelled without causing the death of the individual (Parga 2012); while a poorly handled sea turtle hooked in the mouth can result in the later death of the individual. To increase sea turtles' chances for post-release survival, fishers must be trained in sea turtle safe handling practices and must carry tools for both proper hook removal and cutting line as close to the hook as feasible. These procedures were shown at the symposium in a video that is available for download from the Inter-American Tropical Tuna Commission (IATTC 2011). Therefore, management regulations that require vessels to carry line cutters and hook removal tools have a clear role in circle hook effectiveness.

\section{Circle Hooks and Human Dimensions}

In the context of fisheries and natural resource management, the human dimension refers to the social attitudes, processes, and behaviors that influence decision making, how and why humans value natural resources, how humans want resources 
managed, and how humans affect or are affected by natural resources management decisions (Decker et al. 2001). Human dimensions research recognizes that the solutions to natural resource problems are constrained by political, economic, and cultural institutions, and strives to understand human traits and how they can be incorporated into resource management (Decker et al. 2001). Prior to the International Symposium on Circle Hooks, there were few, if any, published studies on the human dimensions of circle hooks. Cooke et al. (2012) presented the findings from an online snowball survey of recreational anglers that had used circle hooks. The survey revealed that respondent perspectives tended to be consistent with scientific literature. Interestingly, many respondents identified the need for additional education, particularly related to hook setting. In addition, most respondents were apprehensive about broad-scale regulations requiring circle hooks, instead favoring voluntary use or regulation in very specific instances. Given the nature of the survey, Cooke et al. (2012) encouraged the use of regional or fishery-specific social science surveys based on random sampling to further advance understanding of circle hooks and ultimately lead to a reduction in deep hooking and fish mortality.

Other symposium contributions included those from economists interested in how circle hook use in longline fisheries affect technical efficiency, quality of landed product, and the cost of producing desirable outputs (Kirkley and Agar 2012). They applied a mathematical approach, known as data envelopment analysis, to data collected during pelagic longline experimental fishing trails in the northwest Atlantic Ocean, where the performances of J-hooks and circle hooks were compared. Preliminary results suggested that circle hooks reduced bycatch (i.e., undesirable outputs), enhanced overall technical efficiency, reduced production costs, and improved the quality of landed product.

One presentation took an anthropological approach to gauge the perceptions of recreational and commercial fishers with respect to circle hook effectiveness (Stoffle et al. 2012). Specifically, ethnographic methods were applied, whereby key informants were interviewed in such a way that the potential for researcher bias was removed from the data collection process. Results indicated greater variation in opinion within fishery sectors than between them, with economic or conservation concerns shaping most individual's perceptions about circle hook efficacy.

A well-represented group attending the symposium was a team of conservationists and fishery scientists that worked closely with artisanal and commercial longline fishers operating in the eastern Pacific Ocean from Mexico to Peru (Andraka et al. 2012, Martinez et al. 2012, Rendon et al. 2012, Segura et al. 2012). The team applied a "bottom-up" approach, which involved the voluntary testing of circle hook performance aboard fishing vessels during regular fishing operations. Practical obstacles to circle hook deployment (e.g., storage, baiting, rigging, etc.) were confronted and, in many cases, overcome by the fishers themselves. Traditional hooks were readily exchanged for circle hooks when the latter were demonstrated to perform, without interfering with normal fishing operations, equally or better than the former. Gear testing was combined with community workshops and free gear and training were provided for releasing longline-caught sea turtles. A similar approach of cooperative gear testing and community workshops has been used in several Southeast Asian countries (i.e., Indonesia, Philippines, Malaysia, Thailand, and Vietnam) under the auspices of the Southeast Asian Fisheries Development Center, a technical agency involved in the promotion of responsible fishing technologies and practices 
(Chokesanguan and Siriraksophon 2012). The overarching conclusion from efforts of this type is that by building positive, collaborative interactions with fishing communities, conservation measures can be tested, customized, and applied in rapid and effective succession.

Working primarily in Ecuador, another human dimensions research team sought to understand the wide variation in acceptance of US-promoted conservation technologies, including circle hooks and turtle excluder devices (Jenkins et al. 2012). Interviews, surveys, and qualitative, quantitative, and social network analyses revealed that programs burdened with many restrictions such as the US promotion program for turtle excluder devices often yield an inflexible program that does not adequately accommodate cultural and other differences among fishing communities. For improved technology innovation and acceptance, the researchers emphasized the importance of identifying incentives and balancing accountability to rules generated by external governing bodies and giving fishers the liberty to create their own context-appropriate requirements.

Several presentations described outreach efforts to promote circle hooks in US recreational fisheries via state and federal programs including workshops, displays, and presentations at fishing tournaments, public events and professional conferences, youth fishing programs, assembling educator outreach "toolkits," and development of catch-and-release websites, brochures, and online publications (Fluech et al. 2012, Podey and Abrams 2012). Anglers typically are given free samples of circle hooks along with oral, written, and/or digital media instructions on how to successfully use them to catch and, when desired, release fish. Regarding circle hooks in fishing tournaments, one presentation outlined the sequence of events (and evolving perceptions) that led to one of the nation's first marine fishing tournaments to require circle hooks use in its competitive event (Vernon and White 2012). This case study in tournament circle hook adoption served as a template for transitioning other billfish tournaments to mandatory circle hook use throughout the Atlantic Ocean and later to similar tournaments operating in Caribbean and Pacific waters.

\section{Circle Hooks in Assessment and Management}

Consequences of the use of circle hooks include changes in target and bycatch species catchability, although no changes in catchability also can be an outcome. From the stock assessment perspective, unaccounted changes in catchability can result in biases (Cass-Calay et al. 2012). Many assessment models (e.g., virtual population analysis, production models, stock synthesis models, etc.) rely on CPUE series as indices of abundance. When a CPUE is proportional to the stock abundance by a constant value (i.e., catchability coefficient), then it is considered to be an index of abundance. If catchability changes due to, for example, adoption of circle hooks by a portion of or an entire fleet, then the CPUE of that fleet will not be a true index of abundance throughout the time series. Through simulation modeling, Cass-Calay et al. (2012) showed that the impact of these changes in catchability on stock assessment results depend on factors such as the degree of change in the catchability of the fleet(s) in question, and the contribution of that particular fleet(s) to the overall fishery. Under certain circumstances, the impact of changes in catchability on stock assessment results can be highly significant, and to reduce the impact of these changes in stock assessments it is desirable that fleets fish simultaneously with J-hooks and 
circle hooks during a period of time to allow researchers to "calibrate" the CPUE series. However, the adoption of the mandatory use of circle hooks through management regulations usually do not allow this type of comparison to be made. Thus stock assessment scientists recommended that managers take into consideration the potential effects of management regulations that change gear catchability prior to implementing them.

In reviewing existing US regulations mandating the use of circle hooks in commercial and recreational fisheries, Wilson and Diaz (2012) recommended that to maximize the conservation benefits of circle hooks, management regulations should be as consistent as possible through the entire geographical range of the species for which conservation benefits are being sought. Currently, differences in management regulations requiring the use of circle hooks among states and between state and federal waters limit the potential conservation benefits of circle hooks for certain species and fisheries.

Can circle hook adoption have population-level effects? This question was addressed by Walter et al. (2012), who examined the efficacy of a switch to circle hooks to achieve population-level fishery targets for western Atlantic sailfish, Istiophorus platypterus (Shaw in Shaw and Nodder, 1792). They estimated that sailfish landings reductions of $7 \%-8 \%$ would be expected if landings in the non-release fleets remained constant and percentages of circle hook use and live release were both about 25\%. Walter et al. (2012) estimated that circle hook adoption alone would have less than a one percentage point increase in probability of improving the status of the sailfish stock. This exercise underscored that notion that although circle hooks can be a useful tool to convert landed fish to live releases, their use must be combined with other management measures that reduce overall sailfish landings for meaningful population-level benefits to be realized.

\section{Research NeEds}

One of the new research themes emerging from the meeting was the need for incorporation of knowledge and perspectives from other disciplines beyond the present focus on gear technology, fisheries management, and conservation science. For example, rarely have circle hook researchers considered how detailed aspects of animal mouth morphology, dentition, and feeding kinematics influence when and how circle hooks work (Burns and Froeschke 2012). There are obvious opportunities for collaborations with functional morphologists that may be able to model circle hook performance across a range of species and fishing scenarios. There also appears to be ample opportunity to incorporate veterinarian perspectives (see Parga 2012) into the care and handling of circle hook bycatch species and understanding what both shallow and deep hooking means for those animals that do not die in the short term. Finally, given the fact that circle hooks do not always work (and when they do work, stakeholders may not always immediately adopt changes) there is need for a substantial amount of human dimensions research. Incorporation of fisher/angler knowledge and perspectives into the decision making process will ensure maximal likelihood of adoption, when appropriate, and will also identify barriers to the implementation of circle hooks. Human dimensions research would likely be best implemented on a local to regional and/or issue-specific basis. 
Additional research needs include:

- Explicit testing of gradients in Sivertzen's "true circle hook" items (1)-(3).

- Further work determining the pros and cons of different circle hook materials, wire diameters, sizes, and styles (e.g., offset) on different animal species and sizes.

- Determination of species identity, weight, and survival of weak-hook (and monofilament biting) escapees.

- Explicit testing of passive vs active (i.e., setting the hook) fishing and other fisher behaviors that may impact circle hook effectiveness.

- Continuation of research on the addition of appendages to hooks.

- Identification of other bycatch and/or injury reduction techniques such that circle hooks become a component of integrated bycatch reduction strategies.

- Greater use of tag-recapture data to compare hook effects.

- Determination of those factors impeding adoption of circle hook technology by stakeholders, including operational/management constraints.

- Determination of the proper balance of regulation and education with respect to circle hook use on a fishery-by-fishery basis.

- Development of more effective ways of communicating with the artisanal and industrial fishing communities.

- More studies quantifying hook-related catchability changes and populationlevel impacts.

\section{CONCLUSion}

The International Symposium on Circle Hooks served as an important outlet for the discussion of circle hook science and management. This special issue of the Bulletin of Marine Science and its content will serve as a legacy from the event. Here we have attempted to summarize key themes emerging from the symposium as well as those papers presented in the special issue. Moreover, we have generated a research agenda that we believe will help to shape research activities related to circle hooks for the foreseeable future. We hope that the collective benefit of the symposium, the special issue, and this summary article will be meaningful advances in the science and application of such knowledge to inform conservation and management activities. Although in our opinion the symposium was successful and achieved its objectives, the science of circle hooks is far from complete and a number of research needs and management challenges (particularly related to the human dimension) are constraining the ability of circle hooks to make their greatest possible conservation outcome. That said, we also recognize that circle hooks are best considered in the context of an integrated bycatch reduction or fisheries management strategy that includes and/or considers a variety of voluntary and regulatory tools and options. The successes summarized here with circle hooks should not be seen as an excuse to halt seeking other innovative developments that could further advance fisheries management and conservation. 


\section{ACKNOWLEDGMENTS}

We extend our deepest gratitude to the symposium's supporting sponsors whose contributions made every aspect of this symposium a reality. These included: National Oceanic and Atmospheric Administration's National Marine Fisheries Service (NMFS) offices of Protected Resources, Sustainable Fisheries, International Affairs, and Science and Technology; NMFS Southeast Fisheries Science Center; Guy Harvey Ocean Foundation and Guy Harvey Research Institute at Nova Southeastern University; International Seafood Sustainability Foundation; World Wildlife Fund, Fisheries Program; The Billfish Foundation; Ocean Smart; Florida Sea Grant; University of Miami's RJ Dunlap Marine Conservation Program and Rosenstiel School of Marine \& Atmospheric Science; and Tag-A-Giant. A special thanks also to our international delegates B Chokesanguan, R Sagarminaga, and K Yokota, for helping to spread the word about our symposium to specialists in their regions. D DiCarlo superbly handled all logistics from the symposium's inception to its final execution. S Marks, D Die, I Holder, and I Diaz provided key support in symposium planning. We were assisted by numerous University of Miami graduate students and staff that helped make the event a success. Hook illustrations were produced by J Javech who worked from original diagrams kindly provided by G Sivertzen ("Dr. Hook"). Finally, we are grateful to all those who contributed papers, abstracts, and/ or oral presentations-their expertise, experience, and perspectives educated and inspired those who attended and will be invaluable as we face present and future challenges in fishery sustainability.

\section{Literature Cited}

Afonso AS, Hazin FHV, Carvalho F, Pacheco JC, Hazin HG, Kerstetter D, Murie D, Burgess G. 2012. Fishing gear modifications to reduce elasmobranch mortality in pelagic and bottom longline fisheries off Northeast Brazil. In: International Symposium on Circle Hooks in Research, Management, and Conservation-Abstracts. Bull Mar Sci. 88:791-815. http:// dx.doi.org/10.5343/bms.2012.1031

Andraka S, Mug M, Hall M, Mituhasi T, Pons M, Parga ML, Zorrilla Domínguez A, Villagran E, Perez S, Jolón M, et al. 2012. Building the foundations towards sustainable fishing, shifting to better technologies using circle hooks and best fishing practices in the eastern Pacific Ocean. In: International Symposium on Circle Hooks in Research, Management, and Conservation-Abstracts. Bull Mar Sci. 88:791-815. http://dx.doi.org/10.5343/ bms.2012.1031

Alós J, Cabanellas-Reboredo M. 2012. Circle hook benefits in marine recreational fisheries: a multi-species approach. In: International Symposium on Circle Hooks in Research, Management, and Conservation-Abstracts. Bull Mar Sci. 88:791-815. http://dx.doi. org/10.5343/bms.2012.1031

Arauz R, Swimmer Y, Boggs C, Bolaños A, Madrigal J. 2012. Field studies to evaluate the efficiency of alternative hooks that facilitate the release of sea turtles and other by-catch species in the Pacific longline mahi-mahi fishery of Golfito, Costa Rica. In: International Symposium on Circle Hooks in Research, Management, and Conservation-Abstracts. Bull Mar Sci. 88:791-815. http://dx.doi.org/10.5343/bms.2012.1031

Beverly S, Chapman L, Sokimi W. 2003. Horizontal longline fishing methods and techniques: a manual for fishermen. Secretariat of the Pacific Community, New Caledonia. 130 p. Available from: http://www.spc.int/coastfish/sections/Development/FDSPublications/ FDSManuals/HLL/HLL.pdf via the Internet. Accessed 27 June, 2012.

Bigelow KA, Kerstetter DW, Dancho MG, Marchetti JA. 2012. Catch rates with variable strength circle hooks in the Hawaii-based tuna longline fishery. Bull Mar Sci. 88:425-447. http://dx.doi.org/10.5343/bms.2011.1052

Burns KM, Froeschke J. 2012. Survival of red grouper, Epinephalus morio, and red snapper, Lutjanus campechanus, caught on J- and circle hooks in the Florida recreational 
and recreational-for-hire fisheries. Bull Mar Sci. 88:633-646. http://dx.doi.org/10.5343/ bms.2011.1057

Caicedo-Pantoja JA, Zapata-Padilla LA, Castellanos-Galindo GA, Gómez Giraldo LS. 2012. Implementation of a sea turtle bycatch reduction program through the use of circle hooks in artisanal bottom longline fisheries in the Colombian Pacific. In: International Symposium on Circle Hooks in Research, Management, and Conservation-Abstracts. Bull Mar Sci. 88:791-815. http://dx.doi.org/10.5343/bms.2012.1031

Cambiè GR, Müıno R, Freire J, Mingozzi T. 2012. Effects of small (13/0) circle hooks on loggerhead sea turtle bycatch in a small-scale, Italian pelagic longline fishery. Bull Mar Sci. 88:719-730. http://dx.doi.org/10.5343/bms.2011.1041

Cass-Calay SL, Walter JF III, Schirripa M. 2012. Using a stock assessment framework to examine circle hooks: exploring changes in catchability and implications for management. Bull Mar Sci. 88:745-754. http://dx.doi.org/10.5343/bms.2011.1070

Chokesanguan B, Siriraksophon S. 2012 Promotion of circle hooks use in Southeast Asia. In: International Symposium on Circle Hooks in Research, Management, and ConservationAbstracts. Bull Mar Sci. 88:791-815. http://dx.doi.org/10.5343/bms.2012.1031

Coelho R, Santos MN, Amorim S. 2012. Effects of hook and bait on targeted and bycatch fishes in an equatorial Atlantic pelagic longline fishery. Bull Mar Sci. 88:449-467. http://dx.doi. org/10.5343/bms.2011.1064

Cooke SJ, Nguyen VM, Murchie KJ, Danylchuk AJ, Suski CD. 2012. Scientific and stakeholder perspectives on the use of circle hooks in recreational fisheries. Bull Mar Sci. 88:395-410. http://dx.doi.org/10.5343/bms.2011.1056

Cooke ST, Suski CD. 2004. Are circle hooks an effective tool for conserving marine and freshwater recreational catch-and-release fisheries? Aquat Conserv Mar Freshwat Ecosyst. 14:299-326. http://dx.doi.org/10.1002/aqc.614

Curran D, Beverly S. 2012. Effects of $16 / 0$ circle hooks on pelagic fishes in three South Pacific albacore longline fisheries. Bull Mar Sci. 88:485-497. http://dx.doi.org/10.5343/ bms.2011.1060

Decker DJ, Brown TL, Siemer WF. 2001. Evolution of people-wildlife relations. In: Decker DJ, Brown TL, Siemer WF, editors. Human dimensions of wildlife management in North America. Bethesda, MD: The Wildlife Society. p. 3-22.

Diaz GA. 2008. The effect of circle hooks and straight (J) hooks on the catch rates and numbers of white marlin and blue marlin released alive by the US pelagic longline fleet in the Gulf of Mexico. N Am J Fish Manage. 28:500-506. http://dx.doi.org/10.1577/M07-089.1

Domingo A, Pons M, Jiménez S, Miller P, Barceló C, Swimmer Y. 2012. Circle hook performance in the Uruguayan pelagic longline fishery. Bull Mar Sci. 88:499-511. http://dx.doi. org/10.5343/bms.2011.1069

Epperly S, Watson J, Foster D, Shah A. 2012. Anatomical hooking location and condition of animals captured with pelagic longlines: the Grand Banks experiments 2002-2003. Bull Mar Sci. 88:513-527. http://dx.doi.org/10.5343/bms.2011.1083

Fluech B, Zimmerman D, Theberge S. 2012. Sea Grant outreach activities with recreational fisheries on the use of circle hooks. In: International Symposium on Circle Hooks in Research, Management, and Conservation-Abstracts. Bull Mar Sci. 88:791-815. http:// dx.doi.org/10.5343/bms.2012.1031

Foster D, Bergmann C. 2012. Bluefin tuna bycatch mitigation research in the Gulf of Mexico pelagic longline yellowfin tuna fishery. In: International Symposium on Circle Hooks in Research, Management, and Conservation-Abstracts. Bull Mar Sci. 88:791-815. http:// dx.doi.org/10.5343/bms.2012.1031

Foster F, Epperly S, Shah A, Watson J. 2012. Evaluation of hook and bait type on the catch rates in the western North Atlantic Ocean pelagic longline fishery. Bull Mar Sci. 88:529-545. http://dx.doi.org/10.5343/bms.2011.1081

Gadea VY, Segura A, Urteaga JA. 2012. Sea turtle bycatch in the longline fisheries in the Pacific off Nicaragua: a preliminary analysis of the effect of different hooks. In: International 
Symposium on Circle Hooks in Research, Management, and Conservation-Abstracts. Bull Mar Sci. 88:791-815. http://dx.doi.org/10.5343/bms.2012.1031

Giffoni B, Azevedo VG, Swimmer Y, Sales G. 2012. Circle hooks and catch rates of target and bycatch species in the longline fishery in the southwest Atlantic Ocean. In: International Symposium on Circle Hooks in Research, Management, and Conservation-Abstracts. Bull Mar Sci. 88:791-815. http://dx.doi.org/10.5343/bms.2012.1031

Gilman E, Zollett E, Beverly S, Nakano H, Davis K, Shiode D, Dalzell P, Kinan I. 2006. Reducing sea turtle bycatch in pelagic longline fisheries. Fish Fish. 7:2-23. http://dx.doi. org/10.1111/j.1467-2979.2006.00196.x

Godin AC, Carlson JK, Burgener V. 2012. The effect of circle hooks on shark catchability and at-vessel mortality rates in longline fisheries. Bull Mar Sci. 88:469-483. http://dx.doi. org/10.5343/bms.2011.1054

Graves JE, Horodysky AZ, Kerstetter DW. 2012. Incorporating circle hooks into Atlantic pelagic fisheries: case studies from the commercial tuna/swordfish longline and recreational billfish fisheries. Bull Mar Sci. 88:411-422. http://dx.doi.org/10.5343/bms.2011.1067

Grixti D, Conron SD, Ryan K, Vercase VL. 2012. Circle versus longshank hooks: comparing hooking locations and recreational catch for juvenile snapper Pagrus auratus and King George whiting Sillaginodes punctate. In: International Symposium on Circle Hooks in Research, Management, and Conservation-Abstracts. Bull Mar Sci. 88:791-815. http:// dx.doi.org/10.5343/bms.2012.1031

Gude A, Pollock K, Meyer A. 2012. Modification of a standard J-hook design allowing selfrelease of fish and reducing mortality risks in caught fish. In: International Symposium on Circle Hooks in Research, Management, and Conservation-Abstracts. Bull Mar Sci. 88:791-815. http://dx.doi.org/10.5343/bms.2012.1031

Guindon K. 2012. A comparison of catching efficiency and hooking location of circle hooks and straight shank ("J") hooks used in the recreational Atlantic tarpon (Megalops atlanticus) fishery of Florida. In: International Symposium on Circle Hooks in Research, Management, and Conservation-Abstracts. Bull Mar Sci. 88:791-815. http://dx.doi.org/10.5343/ bms.2012.1031

Hall MA, Alverson DL, Metuzals KI. 2000. By-catch: problems and solutions. Mar Pollut Bull. 41(1-6): 204-219.

Hataway D, Stokes L. 2012. Investigating the potential for modified circle hooks with wire appendage to reduce hook ingestion rates in incidentally captured sea turtles. In: International Symposium on Circle Hooks in Research, Management, and Conservation-Abstracts. Bull Mar Sci. 88:791-815. http://dx.doi.org/10.5343/bms.2012.1031

IATTC. 2008. Workshop on turtle bycatch mitigation for longline fisheries: experimental design and data analysis. Special Report 17. 49 p. Available from: http://www.iattc.org/ PDFFiles2/SpecialReports/SpecialReport17.pdf.

IATTC. 2011. Learning how to release sea turties. [Downloadable video]. Available from: http://www.iattc.org/Downloads.htm.

Ingram Jr GW, Driggers III WB, Carlson JK, Cortés E. 2012. Effects of wire leaders on size and catch rates of sharks captured on pelagic longline gear. In: International Symposium on Circle Hooks in Research, Management, and Conservation-Abstracts. Bull Mar Sci. 88:791-815. http://dx.doi.org/10.5343/bms.2012.1031

Jenkins LD, Christie P, Nichols WJ, Gaibor N, Mizrahi M, Viña M. 2012. Understanding factors affecting international adoption of circle hooks: a case study of Ecuador. In: International Symposium on Circle Hooks in Research, Management, and Conservation-Abstracts. Bull Mar Sci. 88:791-815. http://dx.doi.org/10.5343/bms.2012.1031

Kaimmer SM, Stoner AW. 2008. Field investigation of rare-earth metal as a deterrent to spiny dogfish in the Pacific halibut fishery. Fish Res. 94:43-47. http://dx.doi.org/10.1016/j. fishres.2008.06.015 
Kaplan IC, Cox SP, Kitchell JF. 2007. Circle hooks for Pacific longliners: not a panacea for marlin and shark bycatch, but part of the solution. Trans Am Fish Soc. 136:392-401. http:// dx.doi.org/10.1577/T05-301.1

Kennelly SJ, Broadhurst MK. 2002. Bycatch begone: changes in the philosophy of fishing technology. Fish Fish. 3:340-355. http://dx.doi.org/10.1046/j.1467-2979.2002.00090.x

Kerstetter DW, Graves JE. 2006. Effects of circle versus J-style hooks on target and non-target species in a pelagic longline fishery. Fish Res. 80:239-250. http://dx.doi.org/10.1016/j. fishres.2006.03.032

Kirkley JE, Agar J. 2012. Mitigating undesirable outputs, improving product quality, and the use of circle hooks. In: International Symposium on Circle Hooks in Research, Management, and Conservation-Abstracts. Bull Mar Sci. 88:791-815. http://dx.doi.org/10.5343/ bms.2012.1031

Leaman BM, Kaimmer SM, Webster RA. 2012. Circle hook size and spacing effects on the catch of Pacific halibut. Bull Mar Sci. 88:547-557. http://dx.doi.org/10.5343/bms.2011.1059

Lewison RL, Crowder LB, Read AJ, Freeman SA. 2004. Understanding impacts of fisheries bycatch on marine megafauna. Trends Ecol Evol. 19:598-604. http://dx.doi.org/10.1016/j. tree.2004.09.004

Martínez J, Rendón L, Parrales M, Villavicencio J, López J, Mituhasi T, Hara Y, Morán G, Torres L, Mug M, et al. 2012. Reducing sea turtle bycatch and improving the management of the Ecuadorian artisanal fisheries using surface longline gear. In: International Symposium on Circle Hooks in Research, Management, and Conservation-Abstracts. Bull Mar Sci. 88:791-815. http://dx.doi.org/10.5343/bms.2012.1031

Meyer KA, Sullivan C, Elle S, Schill D. 2012. Hooking outcomes for circle hooks compared to conventional hooks fished actively and passively for wild trout in six Idaho streams: some unexpected results. In: International Symposium on Circle Hooks in Research, Management, and Conservation-Abstracts. Bull Mar Sci. 88:791-815. http://dx.doi. org/10.5343/bms.2012.1031

Mituhasi T, Hall M. 2011. Hooks used in artisanal longline fisheries of the eastern Pacific ocean. Inter-American Tropical Tuna Commission. La Jolla, California 2011. Available from: http://www.iattc.org/Downloads/Hooks-Anzuelos-Catalogue.pdf

Pacheco LR, Pons M. 2012. Circle hooks and sea turtle ingestion rates in the fisheries of Panama. In: International Symposium on Circle Hooks in Research, Management, and Conservation-Abstracts. Bull Mar Sci. 88:791-815. http://dx.doi.org/10.5343/ bms.2012.1031

Parga ML. 2012. Hooks and sea turtles: a veterinarian's perspective. Bull Mar Sci. 88:731-741. http://dx.doi.org/10.5343/bms.2011.1063

Parkyn DC, Murie D). 2012. Comparison of hook type and capture history and their influences on recaptures of greater amberjack Seriola dumerili in the Gulf of Mexico. In: International Symposium on Circle Hooks in Research, Management, and Conservation-Abstracts. Bull Mar Sci. 88:791-815. http://dx.doi.org/10.5343/bms.2012.1031

Patterson WF, Porch C, Tarnecki ), Strelcheck A. 2012. Effect of circle hook size on reef fish catch rates, species composition, and size in the northern Gulf of Mexico recreational fishery. Bull Mar Sci. 88:647-665. http://dx.doi.org/10.5343/bms.2011.1086

Podey A, Abrams R. 2012. Promoting the use of circie hooks to Florida's recreational saltwater anglers. In: International Symposium on Circle Hooks in Research, Management, and Conservation-Abstracts. Bull Mar Sci. 88:791-815. http://dx.doi.org/10.5343/ bms.2012.1031

Read AJ. 2007. Do circle hooks reduce the mortality of sea turtles in pelagic longlines? A review of recent experiments. Biol Conserv. 135:155-169. http://dx.doi.org/10.1016/j. biocon.2006.10.030

Rendón L, Parrales M, López J, Villavicencio J, Mituhasi T, Hara Y, Torres L, Morán G, Guerrero P, Mug M, et al. 2012. Sea turtle bycatch reduction program in the eastern Pacific: an awareness and education strategy for fishers in Ecuador. In: International Symposium on Circle 
Hooks in Research, Management, and Conservation-Abstracts. Bull Mar Sci. 88:791-815. http://dx.doi.org/10.5343/bms.2012.1031

Rice PH, Serafy JE, Snodgrass D, Prince ED. 2012. Performance of non-offset and $10^{\circ}$ offset 18/0 circle hooks in the United States pelagic longline fishery. Bull Mar Sci. 88:571-587. http://dx.doi.org/10.5343/bms.2011.1095

Richards PM, Epperly S, Watson J, Foster D, Beideman N, Bergmann C. 2012. Can circle hook offset combined with baiting technique affect catch and bycatch in pelagic longline fisheries. Bull Mar Sci. 88:589-603. http://dx.doi.org/10.5343/bms.2011.1085

Robbins WD, Peddemors VM, Kennelly ST. 2011. Assessment of permanent magnets and electropositive metals to reduce the line-based capture of Galapagos sharks, Carcharhinus galapagensis. Fish Res. 109:100-106. http://dx.doi.org/10.1016/j.fishres.2011.01.023

Rudershausen PJ, Buckel JA, Gregory R, Averett T, Bolton G, Conn, P. 2012. A comparison between circle hook and J hook performance in the dolphinfish, yellowfin tuna, and wahoo bluewater troll fishery off North Carolina. In: International Symposium on Circle Hooks in Research, Management, and Conservation-Abstracts. Bull Mar Sci. 88:791-815. http:// dx.doi.org/10.5343/bms.2012.1031

Sales G, Giffoni BB, Fiedler FN, Azevedo VG, Kotas JE, Swimmer Y, Bugoni L. 2010. Circle hook effectiveness for the mitigation of sea turtle bycatch and capture of target species in a Brazilian pelagic longline fishery. Aquat Conserv Mar Freshwat Ecosyst. 20:428-436. http://dx.doi.org/10.1002/aqc.1106

Santos MN, Coelho R, Fernandez-Carvalho J, Amorim S. 2012. Effects of hook and bait on sea turtle catches in an equatorial Atlantic pelagic longline fishery. Bull Mar Sci. 88:683-701. http://dx.doi.org/10.5343/bms.2011.1065

Sauls B, Ayaia O. 2012. Circle hook requirements in the Gulf of Mexico: application in recreational fisheries and effectiveness for conservation of reef fishes. Bull Mar Sci. 88:667-679. http://dx.doi.org/10.5343/bms.2011.1055

Segura A, Mug M, Andraka S, Pons M, Porras A. 2012. Preliminary results of experiments with circle hooks size C15/0, C16/0, and C18/0 vs J-type hooks in the longline fishery in Costa Rica. In: International Symposium on Circle Hooks in Research, Management, and Conservation-Abstracts. Bull Mar Sci. 88:791-815. http://dx.doi.org/10.5343/ bms.2012.1031

Serafy JE, Kerstetter DW, Rice PH. 2009. Can circle hook use benefit billfishes? Fish Fish. 10:132-142. http://dx.doi.org/10.1111/j.1467-2979.2008.00298.x

Serafy JE, Diaz G, Shivji M, Swimmer Y, editors. 2012a. Proceedings of the International Symposium on Circle Hooks in Research, Management, and Conservation. Bull Mar Sci. Vol 88 no 3. 454 p. Available from: http://www.ingentaconnect.com/content/umrsmas/ bullmar

Serafy JE, Orbesen ES, Snodgrass DJG, Beerkircher LR, Walter JF. 2012b. Hooking survival of fishes captured by the United States Atlantic pelagic longline fishery: impact of the 2004 circle hook rule. Bull Mar Sci. 88:605-621. http://dx.doi.org/10.5343/bms.2011.1080

Stoffle BS, Allen D, Snodgrass D, Orbesen E, Crosson S, Perruso L, Contillo J. 2012. Perceived effectiveness of circle hooks: an examination of US commercial and recreational fishers. In: International Symposium on Circle Hooks in Research, Management, and ConservationAbstracts. Bull Mar Sci. 88:791-815. http://dx.doi.org/10.5343/bms.2012.1031

Stokes LW, Epperly S, McCarthy K. 2012. Relationship between hook type and hooking location in sea turtles incidentally captured in the United States Atlantic pelagic longline fishery. Bull Mar Sci. 88:703-718. http://dx.doi.org/10.5343/bms.2011.1074

Stroud EM, Rice PH, O'Connell CP. 2012. Effects of SMART ${ }^{\text {TM }}$ circle hooks on shark feeding behavior and catch rate. In: International Symposium on Circle Hooks in Research, Management, and Conservation-Abstracts. Bull Mar Sci. 88:791-815. http://dx.doi. org/10.5343/bms.2012.1031

Swimmer Y, Wang J, Arauz R, McCracken M. 2010. Effects of hook offsets on target species catch rates and sea turtle bycatch in a shallow Costa Rican longline fishery. Aquat Conserv Mar Freshwat Ecosyst. 20:445-451. 
Tallack SML, Mandelman, J. 2009. Do rare-earth metals deter spiny dogfish? A feasibility study on the use of electropositive "mischmetal" to reduce the bycatch of Squalus acanthias by hook gear in the Gulf of Maine. ICES J Mar Sci. 66: 315-322. http://dx.doi.org/10.1093/ icesjms/fsn 215

Vernon J, White S. 2012. Incorporating mandatory circle hook conservation into the south Florida tournament circuit: the Miami Billfish Tournament example. In: International Symposium on Circle Hooks in Research, Management, and Conservation-Abstracts. Bull Mar Sci. 88:791-815. http://dx.doi.org/10.5343/bms.2012.1031

Villagran E, Perez S, Ixquiac M, Lopez R. 2012. Experiments with circle hooks for the reduction of incidental catches of marine turtles in the artisanal fisheries for dolphinfish and sharks off Guatemala. In: International Symposium on Circle Hooks in Research, Management, and Conservation-Abstracts. Bull Mar Sci. 88:791-815. http://dx.doi.org/10.5343/ bms.2012.1031

Walter JF, Orbesen ES, Liese C, Serafy JE. 2012. Can circle hooks improve western Atlantic sailfish, Istiophorus platypterus, populations? Bull Mar Sci. 88:755-770. http://dx.doi. org/10.5343/bms.2011.1072

Watson JW, Epperly SP, Shah AK, Foster DG. 2005. Fishing methods to reduce sea turtle mortality associated with pelagic longlines. Can J Fish Aquat Sci. 62:965-981. http://dx.doi. org/10.1139/f05-004

Watson JW, Kerstetter DW. 2006. Pelagic longline fishing gear: a brief history and review of research efforts to improve selectivity. Mar Technol Soc J. 40(3):6-11. http://dx.doi. org/10.4031/002533206787353259

Wilson JA, Diaz GA. 2012. An overview of circle hook use and management measures in US marine fisheries. Bull Mar Sci. 88:771-788. http://dx.doi.org/10.5343/bms.2011.1061

Yokota K, Mituhasi T, Minami H, Kiyota M. 2012. Perspectives on the morphological elements of circle hooks and their performance in pelagic longline fisheries. Bull Mar Sci. 88:623629. http://dx.doi.org/10.5343/bms.2011.1066

Date Submitted: 11 May, 2012.

DATE ACCEPTED: 26 June, 2012.

Available Online: 5 July, 2012.

Addresses: (JES, GAD) NOAA Southeast Fisheries Science Center, National Marine Fisheries Service, Miami, Florida 33149. (SJC) Fish Ecology and Conservation Physiology Laboratory, Department of Biology, Carleton University, Ottawa, Ontario, Canada. (JEG) Department of Fisheries Science, Virginia Institute of Marine Science, College of William and Mary, Williamsburg, Virginia 23062. (MH) Inter-American Tropical Tuna Commission, La Jolla, California 92037. (MS) Guy Harvey Research Institute, Nova Southeastern University, Dania Beach, Florida 33004. (YS) NOAA Pacific Islands Fisheries Science Center, National Marine Fisheries Service, Long Beach, California 92037. Corresponding Author: (JES) Email: <joe. serafy@noaa.gov>.

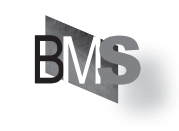

